\title{
Turkish Migration Policy from the 1960s Until Today: What National Development Plans Tell Us
}

\author{
Hakan Kilic $^{1}$ (D) Gudrun Biffl $^{1}$ (D)
}

Accepted: 14 October 2021 / Published online: 22 December 2021

(c) The Author(s) 2021

\begin{abstract}
This paper is on migration and migration policy transition of Turkey. The focus is on the Turkish National Development Plans from the 1960s until today and the sociopolitical and economic context. We identify three distinct periods. The first period of the 1960s is characterized by an explicit support of out-migration to reduce population pressure and on remittances to promote economic growth. The second period from the 1970s to 2000 is marked by diaspora policies of Turkey relative to Europe, thereby acknowledging the role of the Turkish diaspora in the promotion of Turkish economic development and international relations. Since the year of 2000, Turkish migration policy turned to the promotion of highly skilled immigration, aiming at the promotion of technological progress towards a knowledge society with the support of intellectual elites. The policy transition towards the promotion of highly skilled immigration goes hand in hand with institutional and legal changes, which we specify.
\end{abstract}

Keywords Highly skilled migration · Immigration policies · Development $\cdot$ Turkey

\section{Introduction}

International migration research has for a long time given little attention to the role of nation states as drivers of international migration, so Massey (1999, p. 303). This picture has changed since the 1990s though, as nation states became increasingly perceived as actors (Lodewyckx et al., 2010; Basch et al., 1994/2015; Thränhardt, 2003). But the focus continues to be on migrant receiving countries rather than sending countries. This is surprising, given the significant impact of migration on the development of sending countries. Migration does not only affect their demographic and socio-economic situation, but also their political and national security strategies

Hakan Kilic

hakan.kilic@donau-uni.ac.at

1 Department for Migration and Globalization, Danube University Krems, Dr.-Karl-Dorrek-Straße 30, 3500 Krems, Austria 
as well as their international relations (Meyers, 2000). We want to contribute to filling this gap by focussing on a major sending country of migrants in Turkey. While Turkey has been a subject of migration research for a long time, particularly in the context of "guest worker" migration (Abadan-Unat, 1976, 2011; Martin, 1991; Penninx, 1982), remittances and their contribution to the national development of Turkey (Içduygu, 2006; Straubhaar, 1986), as well as the transition from a country of emigration to a country of transit and immigration (Düvell, 2020; Kirişci, 2007), the Turkish strategy on migration has received little attention. We focus on this understudied topic, namely the State Planning Organisation (SPO) of Turkey (Devlet Planlama Teşkilatı), its role in shaping Turkish migration policy as documented in the national development plans (NDPs), and the political and economic context. The NDPs are "government's statements of what it intends to do or not do with regard to the selection, admission, settlement and deportation of foreign citizens residing in its country" (Bjerre et al., 2015, p. 559). They help us understand the development of Turkish migration policies, although the degree to which governments followed them varied across time. We examine the 5-year development plans of the SPO from the early 1960 s till today.

The SPO was founded in 1960 as an advisory organ under the government's authority and was integrated into the newly established Ministry of Development in 2011. The SPO was one of the most important governmental agencies, providing an analysis of the status quo of the socio-economic situation and advising on policies to promote economic, social and cultural development. The implementation and governance of the various policy proposals fell into the responsibility of various administrative actors, in the early period of organised and controlled migration it was the Turkish Employment Agency - TEA (Işs ve Isş̧i Bulma Kurumu- IŞKUR), in the later stage also TÜBITAK (Türkiye Bilimsel ve Teknolojik Araştırma Kurumu), the Scientific and Technological Research Council of Turkey.

The role attributed to migration changed from promoting out-migration of largely low-skilled natives in the 1960s to supporting university education abroad from the 1970s until today, and immigration of the highly skilled from 2000 onwards. Over this time span of more than 50 years, Turkey underwent all stages of a migration cycle, beginning as a country of emigration, and turning into a country of immigration. Before addressing the various phases of Turkish migration, we focus on NDPs and their role in the development of national policy strategies, followed by an account of the research design and theoretical foundations of Turkish migration, the socio-economic context of migration policy and some accompanying institutional and legal changes, and some of the outcomes of migration policies addressed in the NDPs.

\section{Development and the Turkish Development Plans}

Development planning was implemented in Turkey after the military coup in 1960, with the support of international organisations, to promote economic growth, mobilise resources, foster foreign investment and initiate major structural reforms (Paine, 1974, p. 29; Dösemeci, 2013, p. 628; Milor, 1990, p. 2). Although the SPO had 
constitutional status, the NDPs' proposals were only conceived as policy guidelines. They were largely adhered to from 1965 to 1980 (Abadan-Unat, 2011). These development plans were not the first in the history of Turkey, as Tuncer (1971, p. 5) points out. The first Five-Year Industrialisation Plan was implemented in 1934, with a focus on investment in consumer goods industries, mining and power plants, the second in 1938, emphasising the development of heavy industry. This second plan was according to Tuncer (1971, p. 5), barely implemented when WWII broke out. Nonetheless, improved transport (railroads) and seed investment in industries had put Turkey on the road of economic development. In addition, Turkey could forge closer links with the Western World. It became a member of the United Nations (1945), of the International Monetary Fund (1947), and the North Atlantic Treaty Organization (1952). The transition from one-party rule in 1938 (after the death of Atatürk) to a multi-party system brought the Democratic Party-DP (Demokrat Parti) to power in 1950. The ensuing period is referred to by Dösemeci (2013, p. 631) as the "Planless Decade". The government rejected planning to the extent that it did not even implement the economic reforms requested by USA as a condition for Marshall Fund Aid. When the economic upswing of the early 1950s came to an end, the servicing of foreign debt was no longer possible and new credits were hard to get as, according to the creditors, aid money had been used inefficiently and spent on populist actions (Erat \& Arap, 2017). The ensuing economic and political turmoil paved the way for the military coup and takeover in 1960, which brought a new beginning to development planning.

The term 'Development' is complex and has different connotations, depending on national and international context as well as development focus, be it on socioeconomic, human, cultural or environmental development, to name just a few. Development is a process, implying constant change, driven by various actors and actions. According to Todaro (1980) development is "a multi-dimensional process involving changes in structures, attitudes and institutions as well as the acceleration of economic growth, the reduction of inequality and eradication of absolute poverty". Development is therefore a future-oriented process of transformation from a traditional to a 'modern' society. In this sense, a NDP is a road map of a state to achieve specific economic, social and political goals. The fact that more and more countries design NDPs-between 2006 and 2018 the number of countries has more than doubled (from 62 to 134) (Chimhowu et al., 2019)_indicates that NDPs are seen as effective policy instruments of governments to influence, guide and control change. According to Lewis (1979), several countries in Asia, Africa and Latin America began to develop NDPs after the Second World War. Turkey pursued a process of socio-economic development and modernization by designing NDPs as policy guidelines. The first NDP of 1963 informs about the objectives:

"To enable human rights and freedoms, national solidarity, social justice for individuals and society, to realize and secure their peace and well-being, which the Turkish nation has chosen through the democratic order and is openly stated in our constitution, and to end arbitrary and unplanned behaviour, to achieve full employment and human dignity: In order to increase national savings, to realize investments for the benefit of the society of eco- 
nomic, social and cultural development in a democratic way, the first fiveyear (1963-1967) development plan was prepared" (State Planning Organization, 1963).

In analysing NDPs, we enter uncharted waters as far as migration research of Turkey is concerned. Due to the complexity of human migration, various policy issues are involved, spanning from economic and social policy to demographic, regional, cultural and human resource development as well as international relations (Düvell, 2014). In the Turkish NDPs, migration is featured in the context of population, regional and structural policy, aiming at a reduction of population pressure and poverty, of education policy to raise the competence level of natives, thereby wanting to reduce the need for skilled immigration, of industrial and employment policy to diversify industrial output, thereby aiming at boosting economic and productivity growth. But migration policy is also perceived as a means to obtain foreign currency via remittances. The latter impact on the micro-level-by stabilising income of migrant sending families and communities, as well as the macro-level, e.g., by fostering investment (Lubambu, 2014). All these issues are addressed in the NDPs in various policy combinations and stages of socio-economic development. To capture this complexity of issues in the NDPs, we take a holistic analytical approach and link migration to the often-changing mix of policies. In so doing, we can identify three distinct phases of policy development relative to migration. The three phases can be distinguished by the kind of issues addressed; transitions from one phase to the other are identified by a changing mix of issues relative to migration. In phase 1 , the focus lies on the promotion of emigration to alleviate population pressure emanating from substantial population growth; the population pressure was exacerbated by large-scale internal migration of landless agricultural workers to cities. At this stage, no plans existed to upgrade native human resources. In the second phase, the policy focus was on the promotion of Turkish identity of the increasing number of Turkish migrants in Western Europe (diaspora policies) and on international relations with the European Community; in addition, return migration of skilled Turkish diaspora was becoming an issue. In the third phase hyper-selective, highly skilled immigration policies entered the scene, while continuing to promote return migration of skilled Turkish diaspora.

Figure 1 presents the three phases of NDPs in a timeline; the bars identify the number of mentions of various policy issues addressed in connection with migration - an expected positive impact of migration on an issue or policy field receives a plus-sign and issues which have a perceived negative effect on socioeconomic development but are expected to be alleviated by migration get a minus-sign attached. The number of mentions determines the length of the bar. Accordingly, the negative black bar in the 1st NDP identifies population pressure as a major policy challenge, which could be alleviated to a certain extent by exporting labour migrants, represented by the (shorter) positive red bar.

The second vertical axis refers to the weight and significance attributed to skilled labour policies for socio-economic development of Turkey; among them skilled return migration, diaspora policies as well as education reform and training measures for natives in Turkey. 


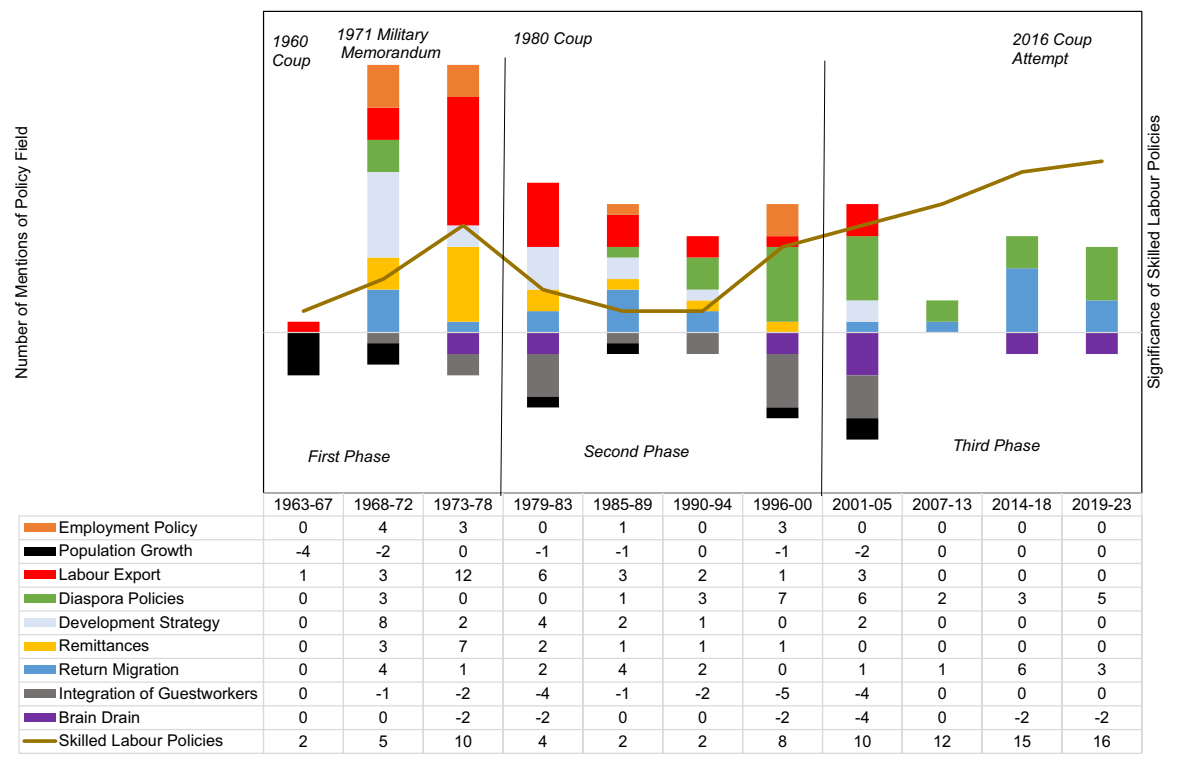

Fig. 1 The three phases of Turkish migration policy in the NDPs and the weight given to highly skilled labour policies. Source: Own diagram

In the first NDP (1963-1967) emigration was the major concern, expecting to thereby reduce population pressure and poverty. In the second and third NDP (1968-1978) migration policy was linked to more than one political concern; emigration (labour export) was increasingly promoted to also procure remittances (positive yellow bar); but the return of 'guest-workers' constituted a policy challenge (negative grey bar). The European guest worker model (Castles, 1986, 2006; Martin, 1981; Martin \& Miller, 1980) was based on a maximum of 1 year; in Germany, 2 -year employment contracts and resident permits. An expiration of the work permit went hand in hand with the loss of residence rights; this allowed destination countries to quickly adjust migrant employment to economic demand fluctuations. The return of the laid-off labour migrants and the ensuing rise in unemployment was a policy challenge for Turkey, sparking the idea of linking return migration of guest workers with investment plans and bilateral investment treaties. However, in addition, bilateral migration agreements were expanded to other countries, e.g., to Australia and Libya.

Another issue mentioned for the first time in the third NDP was brain drain, as not only un- and semi-skilled workers left Turkey but also significant numbers of highly skilled Turkish citizens - many of them were refugees escaping from the military coup in 1971 and the years thereafter.

The following 4th NDP (1979-1983) marks the beginning of the second phase of migration policy in Turkey, when Turkey decided on so-called diaspora policies relative to Europe. The Turkish diaspora had grown to such an extent in Europe that it could be used as a political leverage to promote Turkey's ambition of accession to the European Common Market (Düvell, 2014). In 1980, brain drain became an issue 
again (4th NDP), to some extent the result of the military coup which sent a lot of refugees abroad, many of them Kurds but also supporters of the far-left as well as the far-right political opposition (Sirkeci et al., 2012, p. 38).

The re-integration of former guest workers, many of them from Germany, who took advantage of the financial support granted by the law of 1983 promoting return migration $^{1}$ (Hönekopp, 1987), sparked investment in infrastructure and employment projects (positive light brown bar). We see a decline in the promotion of emigration and a rising focus on the Turkish diaspora in the various destination countries in Europe. In the 7th NDP (1996-2000) skilled emigration (brain drain) featured again as a major policy issue. Turkey responded with the promotion of return migration of highly skilled Turkish (origin) migrants. In addition, education reforms became a national target, raising compulsory education from 5 to 8 years in 1997, to enhance the educational attainment levels of the native workforce (Dulger, 2004; Lindquist, 2017).

With the 8th NDP (2001-2005), we enter the third phase of migration policy in Turkey, in which immigration of high-profile academics was introduced as a new policy issue; the return of skilled Turkish origin diaspora remained on the agenda.

Controlled emigration to European countries was formally organised by the Turkish Employment Service-TES (Is ve Isci Bulma Kurumu), in cooperation with the public employment services of countries with whom Turkey entered into bilateral labour recruitment agreements. The first major bilateral labour agreement was with Germany in 1961 (Akgündüz, 1993). Austria, the Netherlands, and Belgium followed in 1964, France 1965, Sweden and Australia in 1967. The rapid development of oil-rich countries in the Middle-East-North-Africa (MENA) region enticed an agreement with Libya in 1975. The outflow of Turkish workers to this region was a welcome alternative to Europe, where the demand for Turkish workers declined in the wake of the economic recession and oil crisis of 1973. According to the official TES figures, some 800,000 Turkish workers were employed in Europe on the basis of these 'guestworker' programmes between 1961 and 1974, the majority in Germany (Akgündüz, 2008). Thereafter, recruitment via the public employment service declined to a mere trickle of an annual average of 2300 until 1980 (Penninx, 1982, p. 787). However, the recruitment bans of Western European countries were not the end of emigration from Turkey to Europe. Family and chain migration ensued, often in the guise of tourism. Employers were party to this type of chain migration as it reduced their recruitment costs of foreign labour. In addition, waves of refugees added to the outflow of Turkish citizens, which remained unrecorded by the Turkish employment service. Accordingly, the actual number of Turkish migrants in Europe, or other countries, e.g.; in the MENA region, where business activities were the main drivers, are higher than data issued by the Turkish Employment Service.

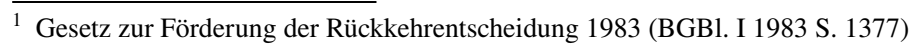




\section{Methodology and Theoretical Underpinnings}

All 11 NDPs of Turkey which have been published since 1963 have been analysed and coded by qualitative content analysis (Mayring, 2014). Based on an intensive literature review (Baumeister \& Leary, 1997) and pre-screening of the NDPs, codes/keywords were determined ahead of the analysis (inductive category formation). Due to changing terminology in the NDPs over time, the codes/keywords were expanded during the first analysis (deductive category assignment) and a second round of analysis was undertaken. Due to the interrelationship of topics and issues, significant parts of the documents had to be analysed in detail in order to identify the context clearly. The method of computer-assisted qualitative data analysis (CAQD) was applied (Kuckartz, 2014). The MAXQDA software was used for both analysis and evaluation (Kuckartz \& Rädiker, 2019).

The document analyses were augmented by expert interviews. One expert is a member of the Scientific and Technological Council of Turkey, an institution devising policies and programmes for highly skilled labour. In this interview the focus was on TÜBITAK's funding programmes and its future direction, given its function as the institutional hub of highly skilled migration policies in Turkey. The other expert is a senior academic scholar from a Turkish University with expertise in international migration and Turkish migration history. The interviews focussed on the multidimensional migration history of Turkey since the 1960s, with special emphasis on Turkey's diaspora policy. For both interviews-conducted in Turkish and recorded on audio-semi-structured interview guides were developed. The MAXQDA was also used for the transcription and qualitative content analysis of the interviews.

The theoretical underpinnings of the migration-development nexus are based on migration transition theory (MT) as a future-oriented concept; we draw attention to the fact that the complexity of migration with the outside world and within Turkey over time cannot be fully explained by it. But MT is adaptable; it does not impose any concise definition on migration and its driving forces and introduces the concept of interconnectedness of various forms of mobility and spaces, as was pointed out by Cooke et al. (2018). In the 1960s and 1980s, the focus of MT had been on the explanation of the historical path of a developing to a developed country (Zelinsky, 1971), perceiving migration, its scope and pattern, as an integral part of socio-economic development. De Haas (2007) and Içduygu (2009a) expanded this theoretical approach by arguing that migration processes are influenced and driven by many actors. Accordingly, not only nation states are taken as agents of migration and thus of development, but also migrants and diaspora communities, together with national and international institutions and stakeholders, like businesses or the World Bank. Thus, migration and development are linked in many ways: while emigration may reduce population pressure in the home country and remittances promote industrialisation, migration also affects the livelihood of migrants, their families and communities at home. In addition, diasporas and transnational communities are agents in the migration-development 
nexus, linking sending and receiving countries and promoting social as well as economic ties, thereby influencing socio-economic development.

Prior to the mid-twentieth century, Turkey's population had been predominantly rural. In 1960, about $70 \%$ of the population lived in rural areas with some $50 \%$ of all farmers being landless tenant farmers or small property owners, who could hardly secure their livelihood from agricultural work (Yildiz \& Köktürk, 1983). At that stage, internal migration from rural to urban areas was not yet taking place. However, substantial (forced) out-migration and in-migration took place as a result of a population exchange agreed upon in the Lausanne Peace Treaty of 1923: Orthodox Christians (Greeks) had to leave for Greece while Muslims (Turks) had to relocate from Greece to Turkey. In addition, Turkish origin migrants-a memento of Turkish settlements in the Ottoman Empire, 'returned' from Bulgaria, Romania and Yugoslavia to Turkey (Akgündüz, 1998, 2013). While this period of Turkey before 1960 may be likened to Zelinsky's Stage one, the "Premodern traditional society", path dependence of historical migration patterns were at play as well, thus blurring this theoretical construction of Turkish migration. The second phase, the so-called early transitional society, falls into the first and part of the second phase of the NDPs; in this phase, massive migration from the countryside to cities occurred. Agricultural reforms had meant to improve the living conditions of tenant and small-scale farmers, but this was only to a limited extent the case, partly because of missed opportunities in land reform, i.e., failing re-distribution of land away from large landowners to tenant farmers, and partly because of a process of massive labour-saving mechanisation and no investment in higher education in rural areas. This hampered the shift of manufacturing from low- to higher-technology, higher value-added goods and sectors requiring higher skills. In addition, Turkey focused on import substitution rather than export-led growth (Karakoç et al., 2017). The consequence were limited employment opportunities and perspectives in rural areas, which triggered the outflow of large numbers of agricultural workers and their families to cities (Guresci, 2013; Ritter, 1972; Tas \& Lightfoot, 2005). At the same time, rapid population growth flowing from high fertility rates and increasing life expectancy due to improved health care increased the population pressure. Only in the 1980s did Turkey embrace an export-led growth policy, thereby increasing industrial exports while at the same time maintaining the value of agricultural exports. The major manufactured export goods were textiles, apparel, leather goods, electrical equipment, chemicals, later also iron and steel products (Arslan \& van Wijnbergen, 1990). In spite of a substantial outflow of Turkish citizens and dynamic, albeit volatile, economic growth from the 1980s onwards, the population size increased according to United Nations Population Data between 1960 and 1990 from 24.5 million to 53.9 million inhabitants, i.e., by 29.4 million or $120 \%$, as can be taken from Fig. 2. Part of this population increase is due to largely forced migration to Turkey, which somewhat offset the outflow of Turkish citizens. The first such inflow resulted from the emigration of the Turkish diaspora in Bulgaria, when more than 350,000 Bulgarian Turks left for Turkey in 1989; they escaped the "revival or rebirth process" of assimilation, a policy pursued by the Bulgarian Communist Party (BCP) (Dişbudak \& Purkis, 2016; Kutlay, 2017; Parla, 2003). This large number of immigrants resulted in an abrupt rise of the labour supply, raising competition in the labour market, which 


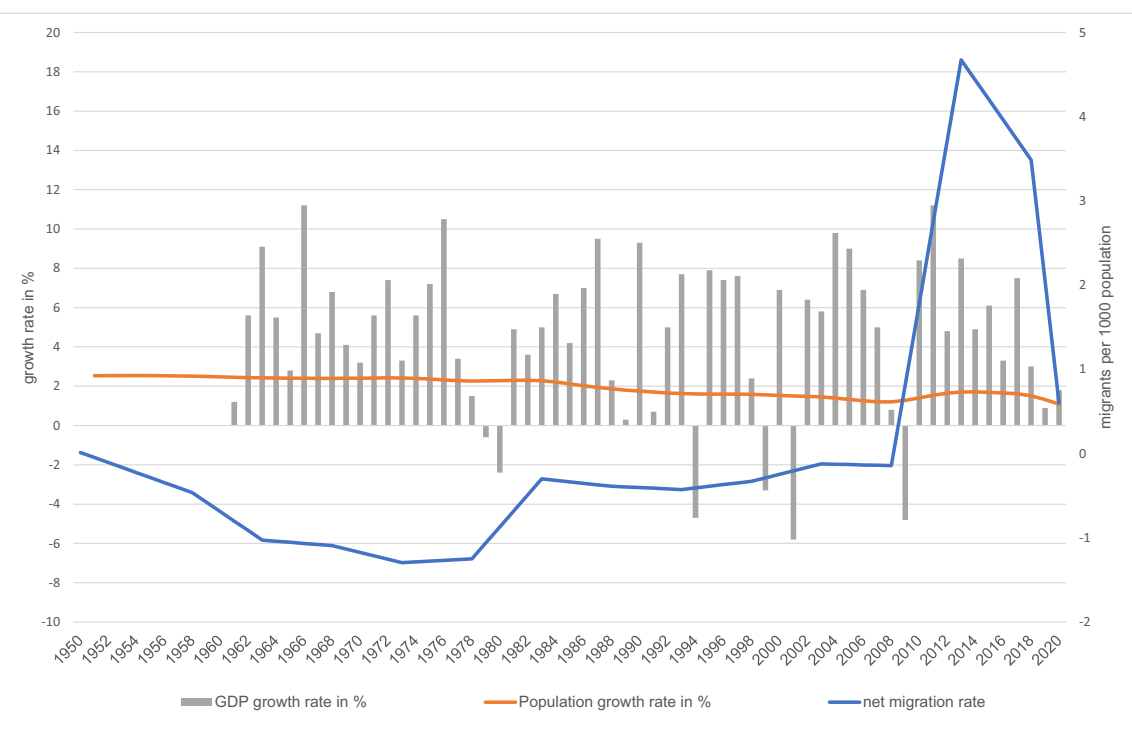

Fig. 2 Development of population, economic growth and net migration in Turkey (1950-2020). Source: www.macrotrends.net; World development indicators

tended to put downward pressure on wages; also, social coherence was jeopardised as the 'Bulgarian Turks' faced increasing rejection by the resident population (Dişbudak \& Purkis, 2016). Furthermore, as pointed out in the 3rd and 4th NDPs, Turkey has not been able to prevent the brain drain of highly skilled and semi-skilled workers, largely due to low wages in international comparison and unsatisfactory working conditions (State Planning Organization, 1979, p. 30; Demet Güngör \& Tansel, 2008).

In the following third stage, the "late transitional society", which characterizes the 1990s (6th and 7th NDP), migration patterns became more complex; while emigration continued, albeit at a reduced pace, return migration of often skilled Turkish diaspora set in; at the same time economic immigrants entered Turkey in search of work as the economy was booming, many of them from nearby countries such as Armenia, Georgia and Azerbaijan. In addition, in 1990, Turkey was confronted with the inflow of refugees from Iraq as a result of the Gulf War; the inflow continued well into 2003, raising the overall number of Iraqi refugees to 500,000 (Sirkeci, 2005). With the war in Iraq, Turkey also lost an important trading partner. The socio-economic consequences were serious, especially in the southeast region, causing company shutdowns, raising unemployment, and setting out-migration to western cities in motion (İçduygu \& Kirişci, 2009; Yayc1, 2019). These decisive events are highlighted in the 7th and 8th NDP's, raising the question of how to respond to the new situation. It was above all the lack of statistics on the demographic, social, and economic characteristics of the inflows that made it difficult for Turkey, according to the SPO, to develop adequate economic and social policies (State Planning 
Organization, 1995, p. 35). In any rate, Turkey became a country of immigration, while at the same time remaining a country of emigration (Içduygu, 2009).

Around the year of 2000, the fourth stage set in, in Zelinsky's term the era of an "Advanced society"; this phase is typical for the 8th to the 11th NDP. Natural population growth declined because of falling fertility rates-in 2019 the total fertility rate dropped below two children per woman. The number of inhabitants continued to rise, but at a lower rate than in the periods ahead. Population growth resulted largely from substantial refugee inflows, beginning in 2009 and reaching an all-time high in 2013 as a consequence of civil war in Syria. The latest numbers suggest a total of 4 million $^{2}$ refugees, largely from Syria, but also from Iraq, Afghanistan and other source countries, the majority receiving temporary protection status (Aksel \& Içduygu, 2018). While the acceptance of this massive influx represents a major humanitarian effort on the part of Turkey, the deal the EU struck with Turkey in 2016 alleviated the most immediate pressure on the Turkish public purse. It entailed financial support—all in all some 6 billion $€$ are envisaged for the period 2016-2024/5 3 , in exchange for allowing the refugees to remain on Turkish territory (Üstuibici, 2019). But Sönmez Efe (2020) drew attention to the fact that the residence of (irregular) migrants on the territory raised issues of integration which fuelled the analysis of Turkish migration policy (Sirkeci \& Pusch, 2016). According to Akgündüz et al. (2015), the inflow of this large number of refugees raised housing and food prices, leaving the employment rates of natives largely unaffected. This was due to the refugees entering to a large extent the informal labour market, thereby depressing wages and working conditions in this already precarious segment of the labour market (Caro, 2020; Tören, 2018; Üstübici, 2019).

Figure 2 shows that Turkey may have reached an equilibrium between outflows and inflows in 2009. From then onwards until 2013, inflows rose more rapidly than outflows as a result of a short-term shock flowing from the Syrian crisis and the consequential inflow of refugees. This goes to show that basic push-pull factors of economic migration can only partly 'explain' the migration developments in Turkey. Too many other factors determine migration flows, e.g., path dependence, family reunion, education (Hazen \& Alberts, 2006), distance (Poot et al., 2016)), as well as political developments. Many of these driving forces, be they economic, social or political, are hard to predict and contribute, therefore, to large variations between sending and receiving countries.

Accordingly, no single theory can capture all factors impacting on migration. But modern theories of migration transition aim at incorporating agency as well as structure in a single concept of socio-economic development. We therefore use it to underpin the decision of the SPO, to engage in diaspora policies, in recognition of the role of migrants in development and the bargaining power of the source country in international relations. One link between the diaspora and development is that they are promoting trade with Turkey via preference and network channels,

\footnotetext{
2 Data from UNHCR, updated as of $27^{\text {th }}$ June, 2021.

${ }^{3}$ For more refer to the EU Facility for Refugees in Turkey, https://ec.europa.eu/neighbourhood-enlar gement/news_corner/migration_en
} 


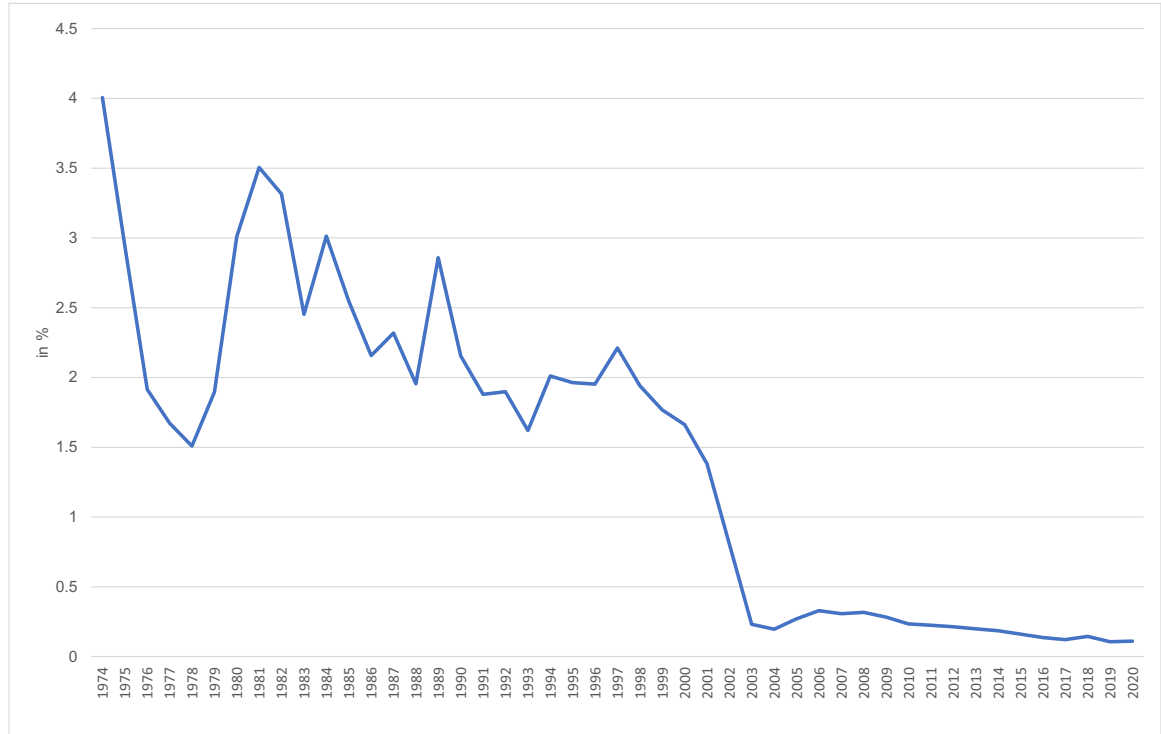

Fig. 3 Personal remittances in \% of GDP to Turkey 1974-2020. Source: World Bank Development Indicators. https://data.worldbank.org/indicator/BX.TRF.PWKR.DT.GD.ZS?locations=TR

since Turkey's exports to Europe are strongly influenced by the preferences of Turkish immigrants for home country products (Biffl, 2012; Insel \& Sungur Cakmak, 2010). The Customs Union Agreement with the EU in 1995, partly flowing from the improved bargaining power of Turkey, boosted the transnational trade link. It follows that the transition of (free) migration from emigration to immigration is linked with market forces and socio-economic development, facilitated by state intervention, which is accompanied by migration policy transition, featuring legal and institutional changes.

\section{The Three Phases of National Development Plans in Context:}

\section{Phase One-1st to 3rd NDP, (1963-1978): Focus on Emigration}

In this first phase, the focus of SPO-Policy advice was on issues of population growth and the associated surplus of labour (Paine, 1974; Straubhaar, 1986), justifying the export of labour and the concomitant inflow of remittances as the preferred policy choice (Martin, 1991); the Western European industrialised countries were the preferred regions of destination (Straubhaar, 1986). Consequently, Turkey entered into labour recruitment agreements with many European countries. In addition, Turkish citizens left on their own account. At the time of the implementation of the first NDP, Turkey was characterized by a lack of political stability and unresolved economic and social problems; the remittances of guest workers became an 
important source of foreign currency, as can be taken from Fig. 3. In 1974, the year the guest worker model came to a halt in Germany, remittances amounted to $4 \%$ of Turkish GDP. With declining numbers of guest workers in Europe, remittances declined until 1978, reaching a low of $1.5 \%$ of GDP. As emigration resumed, largely to the Mena Region, the inflow of remittances to Turkey picked up again, never again reaching the levels of the late 1960s and early 1970s, though.

The skill composition of organised Turkish emigration and the sectoral deployment of the migrants differed by destination country: while the majority of migrants to Europe tended to be un- and semi-skilled, highly skilled ones tended to emigrate to the USA (Gökbayrak, 2012). The following paragraph in the NDP dealing with "manpower, employment, education and research" shows that the emigration of lowskilled surplus labour was the explicit policy choice while the loss of skilled labour was to be prevented:

"Another aspect of employment policy is the export of surplus labour to those countries of Western Europe, which suffer from a dearth of labour. However, Turkey, while having a surplus of unskilled labour, has insufficient numbers of skilled labour. Therefore, it is essential that measures be taken to ensure that Turkey's deficiency in skilled labour not be exacerbated by Turkey's labour export policy" (State Planning Organization, 1963, p. 456).

Turkey embraced the export policy of unskilled labour for at least two reasons: to reduce unemployment and to receive remittances from the migrants (Biffl, 2013). The challenges for economic growth as a result of emigration of skilled workers to the USA and also Europe receive a lot of attention in the NDPs. It is noted that of the 195,000 workers who migrated to western European countries between 1961 and $1966,38 \%$ were tradesmen. $60 \%$ of them were people from the western part of Turkey, which did not correspond to the SPO-plans, according to which workers were to originate from the eastern part of Turkey, where a significant surplus of agricultural workers existed (State Planning Organization, 1967, p. 141).

The SPO's ambitions of the 1960s met with political resistance from the ruling Justice Party-JP (Adalet Partisi) under the Prime Minister Süleyman Demirel. In particular, the struggles over agricultural taxation and the ongoing question of the SPO's autonomy relative to the elected government represented policy challenges during this period (Dösemeci, 2013).

As organised labour migration to Europe declined flowing from the economic downturn in 1973, more and more Turkish workers left for the MENA region (İçduygu \& Sert, 2011; Kirişci, 2000), to a certain extent also to Russia, particularly after 1989 due to the unfavourable conditions created by the Gulf Crises (Düvell, 2020; İçduygu, 2009; İçduygu \& Karaçay, 2012; Ryazantsev, 2009). An agreement between Turkey and Libya in 1975 triggered emigration to Libya. In exchange for crude oil to Turkey 'at preferential rates', Turkey sent 10,000 skilled Turkish workers to Libya (Ronen \& Yanarocak, 2013). In addition, many Turkish companies, in particular in the construction sector, set up businesses in the fast-growing oil-rich countries of the MENA region. These companies employed large numbers of Turkish workers, largely on a project basis. 
In this first phase, Turkey assumed that the emigration of workers to Europe would be of a temporary nature and a means to raise their skills, which could be put to good use in Turkey upon their return, thereby promoting the transformation from an agricultural to an industrial society (State Planning Organization). In a similar vein, the Turkish government sponsored study abroad scholarships to raise the skill level of Turkish workers faster than by relying solely on the national higher education system. While the Turkish authorities expected and even requested the return of students after successful completion of the study abroad programmes, not many did return (Tansel \& Gungor, 2003). This aspect featured as "brain drain" for the first time in the third NDP (State Planning Organization, 1973, p. 81). According to Franck (1970), Turkey lost some 375 highly skilled university graduates annually between 1962 and 1967. According to SPO-estimates, 51.5\% were medical doctors, 40\% engineers, 5.5\% natural scientists and 3\% social scientists (Oguzkan, 1976, p. 78; State Planning Organization, 1973, p. 687).

Accordingly, Turkey lost more skilled workers in the emigration process than other Mediterranean countries (Penninx, 1982). In 1970, according to the German State Employment Department, the skills of workers from Turkey in Germany were the highest of all labour migrants, with $28.2 \%$ skilled workers, followed by Italian workers at 27.1\% (Bundesanstalt für Arbeit, 1970, p. 32). Although the SPO opposed unrestricted out-migration of its citizens, the government supported it because of the remittances flowing from them (Paine, 1974, p. 36). According to Abadan-Unat (2011, p. 36), the host countries benefited from the large number of highly skilled workers among the Turkish migrants, while the brain drain hampered Turkey's development.

The economic recession and the oil crisis of 1973 triggered economic restructuring in Europe, which was accompanied by a drastic reduction of migrant labour. Switzerland and Sweden were the first countries to implement a migration stop in 1970 and 1972 respectively. Others followed: Germany in 1973 and the Benelux countries and France in 1974. However, policies aimed at controlling and reducing migration could not stop out-migration from Turkey. Migrants who had come under labour recruitment programmes increasingly settled in the host countries, as returning to their home country entailed a considerable risk of losing the residence permits. According to a survey among migrants in Germany, potentially permanent residence and work permits boosted family reunification which in turn reinforced the tendency to settle in Germany (Jankowitsch et al., 2000). Although some European governments tried to limit family reunification, these efforts were without success on grounds of human rights anchored in Article 19 of the European Social Charter of 1961 .

\section{Phase Two-4th to 7th NDP (1979-2000): Diaspora Policies, Return Migration and Human Resource Development}

The decline of labour demand for Turkish migrants in the early 1970s had resulted in a shift of migration policy of the Turkish government, as documented in the NDPs. As large numbers of "guest workers" were intent on staying in the various European 
countries (Castles, 1986), diaspora engagement became a political priority of the Turkish government. This point was highlighted by the interviewed senior academic scholar (2019) from a leading Turkish University: "Turkey had no serious diaspora policy between 1960-1990. With the AKP government, an aggressive diaspora regime began which perceives and uses the diaspora as a political instrument". The focus of Turkish diaspora policy towards Europe was to secure and strengthen the labour and social rights of Turkish migrants in the European host countries. Turkey was able to substantiate the rights of Turkish labour migrants in Europe via Decision No 1/80 of the Association Council (Association Council, 1980). In Article 6(1), it is stated that regular Turkish migrant workers and their family members may obtain, after a certain period of legal work, the right to renew their work permits and to extend their residence in accordance with their entitlement to work. Flowing from that concession, a new citizenship law was enacted in Turkey at the beginning of the 1980s, which allowed dual citizenship. In addition, the goals of the "diaspora policy" were raised to constitutional status in the 1982 constitution after the coup d'état in 1980 (Aksel, 2014; Aydin, 2014; Ünver, 2013). To strengthen the relationship between Turkish emigrants and Turkey, the government decided to send Imams and teachers via the Ministry of Education and the Directorate of Religious Affairs (Østergaard-Nielsen, 2016, p. 108). The preservation of ties to Turkey was also facilitated by granting the retention of property rights in Turkey in the 1990s, even when abandoning Turkish citizenship and adopting the citizenship of the host country.

The diaspora policies did not only target family and cultural ties with Turkey. They also addressed the integration of migrant workers in the European host societies. The 4th NDP makes explicit reference to the educational challenges faced by the children of Turkish migrant workers in the destination countries. It suggests ways to improve foreign language learning outcomes (State Planning Organization, 1979, p. 137). The focus on the integration of Turkish (origin) migrants in the respective host countries became, however, a policy dilemma. On the one hand, Turkey was supportive of the preservation of the Turkish culture, traditions and, of course, the Turkish language of the émigrés, on the other it deplored the marginalised living conditions of migrant workers, perceived as a consequence of their, often difficult, economic situation but also a result of segregated housing and the preservation of close Turkish community ties. The latter tended to reduce contacts and communication with the host country communities. In the NDPs, reference is made to the poor economic condition of Turkish migrants as the major culprit for their marginalisation in the host societies (Abadan-Unat, 2011, p. 114; State Planning Organization, 1995, p. 52). Bade (2017) did not share this judgement, at least as far as Germany was concerned, as it did not take the complexity of Turkish migration and integration into account. Bade points out that the integration of Turkish migrants in Germany was good, in particular also the educational achievements of the second generation and their social and occupational mobility, if taking the socio-economic background of the parent generation into account. They fared often better than German blue-collar workers of equal educational attainment and economic situation. Schührer (2018) comes to the same conclusions.

The optimistic expectation of the SPO of the first period that the guest worker model, which was originally intended as a circular migration model, would help Turkey 
to obtain an industrial workforce faster than otherwise did not come to fruition, at least in the short run. Penninx (1982, p. 798) argues on the basis of empirical findings that investment, which was "channelled into small and middle-scale industrial activities through workers' companies and village development cooperatives...has (so far) not yielded the expected contribution to (regional) development." He attributed this to an 'erratic' government policy and a lacking concept of socio-economic development in rural areas. In the long-run, and with the macro-economic policy shift away from import substitution to export-led growth, many of these small- and medium sized enterprises turned to the world market for growth. This strategy was successful and these entrepreneurs became known as Anatolian tigers (also referred to as Islamic Calvinists-(ESI, 2005), bringing economic growth and development to Anatolia, one major source region of migrants (Demir et al., 2004). In addition, the stabilisation of political and economic governance helped attract foreign investment, thereby boosting economic growth, as Arslan and Ökten (2010) demonstrate.

The intensification of diaspora policies and the positive economic development of Turkey from the 1980s onwards, which was driven by increased trade with Europe, foreign investment and privatisation, boosted industrialisation of the Turkish economy (Biffl, 2012). Turkish business start-ups in Europe had become important drivers of trade between Europe and Turkey. The economic upswing accelerated industrial restructuring of Turkey, raising demand for skilled workers. As a result, Turkey engaged in the promotion of 'return' migration with a focus on the second generation, preferably highly skilled ones. In spite of that policy reorientation, Turkey experienced a persistent brain drain during this period. This was no longer the result of foreign worker recruitment by the major European destination countries, but rather a result of family reunion, to a certain extent also of political instability in Turkey. In that vein, the military coup of 1980 sent large numbers of often highly skilled asylum seekers abroad. But it was also specific academic professions emigrating in no small numbers, e.g., medical doctors, who had good employment and career prospects in Europe (Peppler, 2018). In addition, large wage differentials and better professional perspectives enticed highly skilled Turkish citizens to leave Turkey for Europe or the USA. At the beginning of the 1980s, highly qualified Turkish migrants represented the largest group of all non-EU university graduates living in West Germany. About 1280 of them were medical doctors. Paine (1974) concludes that one-sixth of the Turkish migrants to Germany were highly skilled according to German criteria, and that Turkish workers of all skill levels earned three to four times more than they could have earned in Turkey.

In this situation of an increasing competition for qualified workers, Turkey decided to invest in becoming an "Information Society". Consequently, in the 7th NDP, this development strategy was introduced, together with guidelines towards this end, acknowledging that the demand for skilled workers would increase with technological advances. Accordingly, Turkey decided on investing in its people as the best way to further economic development and social progress (State Planning Organization, 1995, pp. 3-5). Betcherman et al. (2008) had already much earlier identified insufficient investment in human capital as a crucial factor for the limited sustainability of economic growth in Turkey. 


\section{Phase Three-8th to 11th NDP (2001-2023): Highly skilled Immigration Policies}

The third phase which encompasses the last 20 years of Turkish politics was governed by the Justice and Development Party-AKP (Adalet ve Kalkinma Partisi). The AKP ended two decades of unstable coalition governments and successive economic crises and initiated the so-called "golden years" of government in the 2000s, stabilising economic growth by engaging in a type of regulatory neo-liberalism. It can be taken from Fig. 2 that economic growth picked up after the recession of 2001 and remained strong throughout the planning phase, dipping only in 2009 in line with the global recession. Economic growth has, however, lost momentum since 2017, possibly flowing from the aftermath of the attempted coup of 2016. While the first phase of development until 2010 was marked by a process of democratisation, the second half resorted to a centralization of power employing a state-led developmentalism, which is accompanied by institutional reforms (Öniş, 2019). Accordingly, the SPO was replaced or rather integrated into the Ministry of Development and as such became an important player in the economic bureaucracy in the post-2011 era (Yilmaz \& Güler, 2016).

The focus of migration policy turned to highly skilled immigration. This has been an established policy orientation of many developed as well as developing economies for some time (Boeri, 2012; Cerna, 2016; Czaika, 2018). Turkey joined this group of countries at the turn of the century and implemented various policy instruments to attract highly skilled migrants deemed fruitful for the development of Turkey. This objective is featuring in the 10th NDP.

"Demand for skilled labour is envisaged to increase worldwide. [...] The $21^{\text {st }}$ century will be a century in which countries want to attract qualified human resources on a global scale, besides training qualified human resources themselves, we want to use this power correctly and appropriately (...)" (Republic of Turkey. Ministery of Development, 2013, pp. 11-12).

This statement is indicative of the abandonment of emigration policies and the reorientation towards selective immigration policies. In consequence, and because of successful economic development, Turkey experienced a reduction in population outflows and a rise in population inflows, as migration transition theory would have us expect (Kirişci, 2000; Sirkeci et al., 2016). With the focus on export-led growth, it was above all the integration of Turkey in global markets and value chains that stabilised economic growth. Formal as well as informal remittances continue to play a vital role for the wellbeing of migrant sending communities, but overall remittances are declining with increasing settlement tendencies of the Turkish diaspora in the various host countries (Içduygu, 2006).

While a concrete implementation plan for skilled immigration was presented as late as the 10th NDP, the initial ideas and the need for highly skilled manpower and its recruitment from abroad were already voiced in the 9th NDP. "... employment of foreign researchers in specific fields in Turkey will be supported" (Turkish Republic Prime Ministry. State Planning Organization, 2006, p. 88). The concrete implementations of the policy priorities of the 9th NDP are the grant and fellowship programmes of TÜBITAK, which have been initiated in 2010. The stated goal was 
the transformation from an industrial to a knowledge society, by raising productivity and avoiding the middle-income trap en route to a high-income country (Republic of Turkey. Ministery of Development, 2013, p. 8).

Currently, Turkey is, according to the World Bank Classification of Income Groups, positioned among middle-income countries, together with India, China and Malaysia. India and China have already established immigration policies for highly skilled diaspora, particularly from North America. Turkey is a latecomer in this race for talent and is starting from a different vantage point (Cerna \& Czaika, 2020), as for highly skilled 'return' migration to work, a country has to first establish a certain economic, technological and institutional development level upon which highly skilled 'return' migrants can build and promote progress in the information age. This raises the question if Turkey has all it needs to attract the Turkish origin brains abroad to join the workforce in Turkey. While the diaspora policies of Turkey of the 1980s and 1990s had been directed towards ensuring labour and social rights of their diaspora abroad, the improvement of labour and social rights in Turkey has been neglected (Martin, 1991; Müller, 2014). Turkey continues to lose skilled labour, possibly a result of limited labour rights, work safety and working conditions in general in Turkey as the European Working Conditions Survey (Eurofund, 2017) suggests. In addition, political developments may contribute to the loss of highly skilled Turkish workers to western (European and American) countries, as Sirkeci and Zeyneloğlu (2014) suspect. Political developments are also the major reason given in the Global Index of Talent Competitiveness for downgrading Turkey from the 59th position in 2014 to the 78th (out of 132) in 2020.

In the competition for the best brains in the world, Turkey pursued a systematic approach, focusing initially on intellectual brain gain from neighbouring countries by supporting increasing commercial and investment relations. Later the focus was on scientists of Turkish origin from abroad. This approach is a central part of the Qualified Human Resources Program in the 10th NDP. This programme has the objective to increase Turkey's competitiveness and raise its attractiveness on an international level (European Commission, 2018). The aim is to entice highly skilled people of Turkish origin to 'return' to Turkey. To this end, Turkey wants to create an environment and conditions that promote innovation, largely by organising cooperation between universities, industry, the public and private sector and research centres. This open network system is expected to provide the necessary impetus (Republic of Turkey. Ministry of Development, 2014, p. 188). The TÜBITAK Directorate of Science Fellowships and Grant (BIDEB) is responsible for the elaboration, implementation, execution and monitoring of this strategy. Already in 2010, the Scientific and Technological Human Resource Strategy and Action Plan 2011-2016 were established to decide on the roadmap for future policies (OECD, 2012; TÜBITAK, 2010).

Until 2019, TÜBITAK pursued three avenues to attract highly skilled migrants for permanent or temporary stay in Turkey. One of these avenues was the Re-Integration (Repatriation) Research Fellowship Program. It was only accessible for researchers and scientists of Turkish origin living and working abroad. It was available for the period 2010-2018. This programme was based on the policy priorities of the 9th NDP and had the aim of attracting experienced highly skilled Turkish 
origin specialists working in research fields of Natural Sciences, Engineering and Technology, Social Affairs and Humanities, Medical and Agricultural Sciences. The maximum duration of the grant was for a stay of 24 months. It was the first serious attempt of Turkey to invite specific diaspora groups by offering support of various sorts. Over the entire period of the programme, 931 researchers applied, of whom 452 'returned' to Turkey. Although the call addressed people with Bachelor and 6 years of experience, Master with 4 years of experience and $\mathrm{PhD}$ degrees, only scientists were funded who had a $\mathrm{PhD}$ and at least 2 years of experience (full-time employment). The applicants' previous residence countries were USA, Germany, Canada, Austria, England, Italy, Australia, Japan, China, South Korea, Denmark, Holland, Israel and Bosnia (Communications Center of TÜBITAK, 2020). Although the numbers of returnees were moderate, the programme received great publicity and was considered a great success by the government (Demircan, 2020). Many of the scientists of Turkish origin did not settle, though, and left Turkey again because of a reported lack of freedom of expression, the non-autonomous structure of higher education, too much bureaucracy and nepotism in Turkey. As of today, there is no information on how many remained in Turkey.

The second avenue pursued by TÜBITAK built on the former but was adapted in 2018 to become the International Fellowship for Outstanding Researchers Program; it was open for all nationalities and became a flagship project. According to the interviewed TÜBITAK expert (2019), Turkey followed a "salad bowl" approach, favouring diversity to promote innovation and productivity: "What we want is that highly skilled scientists from all countries of the world come to Turkey and follow their research interests here. Turkey is ready to support them in the hope that they will stay, continue doing research and contribute to the development of Turkey." TÜBITAK evaluated the skilled labour migration policies of industrialised countries, in particular of USA, Canada and Australia, and adapted them to Turkish needs. Only qualified researchers with leading scientific and/or technological achievements and international work experience in leading academic, industrial or public institutions, which were of strategic value to Turkey, could apply. All in all, 152 persons with Turkish citizenship applied (91 were funded), and 98 foreign high achievers applied-29 were invited to continue their research in Turkey (Communications Center of TÜBITAK, 2020). In spite of these small numbers, the media reported that the return of Turkish and Turkish origin scientists via this programme was a 'success story' (Öndes, 2019).

The third avenue addressed researchers and scientists of all nationalities who wanted to spend some time in Turkey; one such programme was the Co-Funded Brain Circulation Scheme (currently 133 researchers) and the Fellowships for Visiting Scientists and Scientists on Sabbatical Leave (today some 157 researchers). In addition, the Research Fellowship Program for International Researchers (currently 401 researchers) belongs to this type of programme.

While these programmes are facilitators of in-migration of highly skilled persons, the major driving force of highly skilled in-migration was the establishment of private universities and research institutions in Turkey since the 2000s (Aydin, 2013; Kirilova \& Kilic, 2012; Sanchez-Montijano \& Sökmen, 2018). These institutions tend to attract young academics from abroad who hope for better career options in 
Turkey. Since the language of education is English in almost all private and increasingly also public universities, the lack of Turkish language competencies is no longer a barrier to research work in Turkey (Sanchez-Montijano \& Sökmen, 2018). But outside the research field not many of the skilled migrants find adequate jobs or have career prospects (Içduygu, 2009). As a consequence, unemployment is an issue and may hinder the absorption of larger numbers of skilled returnees (Bilgili \& Siegel, 2014). Also, according to the TÜBITAK expert (2019), the focus is no longer primarily on the ethnic origin of highly skilled people, but on their expertise and their contribution to development of the Turkey: "Through the TÜBITAK programs, Turkey wants to attract top-level highly skilled people. Of course, we want many of them to be of Turkish origin, but this does not mean that they are preferred. It's not a must". From the perspective of Turkish diaspora policy engagement and international relations, it may, however, be of greater advantage for Turkey and its diaspora, if the highly skilled academics remain where they are (Mencutek \& Baser, 2018).

\section{Migration Policy Transition Facilitated by Legislative Change}

All the initiatives to attract highly skilled migrants from abroad are extremely selective. To facilitate their integration in Turkey, legislative changes have been undertaken (Bilgili \& Siegel, 2014). The first legislative measure refers to the Blue Card, which was introduced in 1995 (Law No.4112) and granted to former Turkish citizens, who got permission from the Turkish Ministry of the Interior to abandon their Turkish citizenship to obtain another citizenship; they have the same rights as Turkish citizens (Republic of Turkey, 1995). The main reason for the introduction of the Blue Card was that Germany and several other host countries of Turkish migrants do or did not accept double citizenship (Pusch \& Splitt, 2013). In 2004 (Law No. 5203) and 2009 (Law No. 6304), the regulations were modified, spelling out the rights and duties, but also specifying exemptions from certain obligations of Turkish citizens, e.g., the exemption from military service, the exclusion from active and passive vote and from employment as a civil servant (Republic of Turkey, 2009). The Blue Card was put in place to promote the social, political and economic integration of "guest workers" from Europe and their descendants; it was a means to strengthen ties with and their sense of belonging to Turkey; it was thus an instrument of Turkey's diaspora engagement. With the last amendment of the law in 2012 (Law No. 6304) (Republic of Turkey, 2012), the Blue Card can be obtained up to the 3rd generation of descendants of former émigrés. This card allows unrestricted access to the Turkish labour market and settlement; this scheme became an important instrument of recruitment of highly skilled Turkish origin migrants without cumbersome red tape. It allowed skilled Turkish origin migrants, who did not qualify for the TÜBITAK support programmes, to take advantage of employment opportunities in Turkey (Bilgili \& Siegel, 2014; Kirilova \& Kilic, 2012).

In 2016, a second major legislative change has been introduced, namely a comprehensive labour migration law, the International Labour Force Law 6735. It is directed towards highly skilled persons the Turkish labour market is considered 
to need. It is the basis for a new permit, the so-called "Turquoise Card", which grants some privileges to EU citizens (Sanchez-Montijano \& Sökmen, 2018, p. 13), amongst them the unrestricted right to work and reside in Turkey together with a residence permit to specific groups of their relatives. Article 11.1 (Republic of Turkey 2016) points out that these migrants have to have skills and competences, which may make a contribution to science and technology, and who perform activities and investments that have a positive impact on the Turkish economy (Centel, 2017; OECD, 2017).

The nexus between policy objectives of the NDPs, supporting legislative changes and instruments like the TÜBITAK programmes, is pointed out in the 11th and most recent NDP. It is stated in the plan that "In addition to the Turquoise Card, a mechanism will be established to encourage the inflow of qualified and highly experienced foreign labour [...] Part-time employment of competent academics and researchers from abroad will be promoted at universities via specialized programs in critical technologies [...] The share of qualified foreign academics in total employment will be raised" (Presidency of the Republic Turkey. Presidency of Strategy and Budget, 2019, 75,85,144). The law also defines in Article 11.5 who is considered to be highly qualified: "those with internationally accepted studies in the academic field, those who have come to the forefront in a scientific, industrial and technological area that is considered to be strategic in terms of our country, or those who have made or are anticipated to make significant contributions to the national economy in terms of exports, employment, or investment capacity, shall be deemed as qualified foreigners" (Republic of Turkey 2016).

However, it has become increasingly difficult to entice the brains of the world to migrate to Turkey in the aftermath of the failed coup attempt of 2016. On the contrary, the emigration pressure of Turkish intellectuals has increased as the Turkish government is suspicious of so-called 5th column Turks, i.e., suspected sympathisers of the Gülen movement. According to Eurostat data, the number of Turkish asylum seekers in the European Economic Area and Switzerland has increased from a low of 5500 in 2015 to 27,700 in $2019^{4}$. In addition, in a clampdown on Gülen's supporters, 292,000 people have been detained in the last 4 years, of whom 96,000 have been jailed. More than 130,000 people were fired from public service by emergency decrees (Euronews, 2020; Yavuz \& Balci, 2018).

\section{Conclusion}

The analysis of the NDPs showed that Turkish migration policy took different turns from the early 1960s until today. The role migration was to play in the NDPs changed with the transition of Turkey from an 'early transitional society' in the 1960 s to an 'advanced society' in the years of 2000, in Zelinsky's terminology of migration transition theory. While the main concern in the 1960 s was to alleviate population pressure through emigration, the focus changed as manufacturing

\footnotetext{
${ }^{4}$ For details see Eurostat data code: migr_asyppctza.
} 
industries evolved and diversified, raising the demand for skilled workers. This development prompted a change in migration policy towards the promotion of return migration of skilled Turkish origin migrants. As Turkey was entering a new phase in socio-economic development and aiming at becoming an information society, driven by knowledge and artificial intelligence, immigration of highly skilled manpower moved centre stage as a policy tool.

The NDPs took the respective demographic and socio-economic development of Turkey into account. The benefits expected from migration policy materialised only to a limited extent. While the emigration of low-skilled workers tended to reduce surplus labour and reduce poverty, and remittances helped promote the economic development, the cyclical return-flow of Turkish guest workers from abroad tended to destabilise the Turkish labour market in the 1970s. The expectation that the return migration of Turkish emigrants would speed up socio-economic development could only materialise with the shift from import substitution to export-led economic growth on the one hand and the stabilisation of political and economic governance structures on the other in the 1980s.

Turkey's focus on diaspora policies in relation to Europe from mid-1970 to the 1990s were an important vehicle of political as well as economic relations; the focus on improving the school performance of second and third generation youth, and the upskilling of Turkish migrant workers can be taken as a means to improve opportunities for re-integration in the Turkish labour market. On the other hand, the Turkish diaspora in Europe could be used as a leverage towards Turkey's aspirations of membership to the European Union.

In the 1960s, the preferred countries of destination of the Turkish low-skilled migrants were European. The recruitment agreements between Turkey and various Western European countries confirm that. The economic recession of 1973 and the ensuing recruitment ban in many European countries were the beginning of a diversion of Turkish migrant workers to North Africa and the Golf Region. The skilled and highly skilled Turkish citizens tended to leave for Europe and North America, partly to escape political persecution in Turkey in the wake of military coups, partly in a quest for improving their career options.

The experience shows that emigration from Turkey to Europe and other areas of the world was largely the result of explicit Turkish policy initiatives. It flowed either from bilateral agreements or from international economic, political and historic linkages, e.g., in the MENA region and countries of the former Soviet Union. But emigration was also a result of chain migration, e.g., to USA and Europe after the end of the guest worker programmes, as well as political upheavals in Turkey, in particular the refugee outflows of ethnic minorities and political dissidents in the wake of military coups in 1971 and 1980.

The reduction of population growth, which went hand in hand with an improved socio-economic situation of Turkey, paved the way for the transition to a knowledge society. Towards this end, Turkish migration policy moved away from promoting emigration to fostering skilled immigration from 2000 onwards. The preferred group of highly skilled immigrants was of Turkish origin, most of them from Europe and North America. 
Thus, Turkey has moved from being an emigration country to becoming an immigration country. While many of the immigrants are from various corners of the world, many of them descendants of former emigrants, the quest for highly skilled immigration could only be satisfied to a limited extent by the specific support programmes put in place since the early years of 2000. This is largely because countries can only attract and retain talent if they offer an effective immigration package including career prospects, attractive salaries, personal freedoms and a stable political situation. Such comprehensive arrangements have not come forward, indicating that the policy strategy as documented in the NDPs was not sufficiently underpinned by adequate measures and institutional support.

Acknowledgements The authors would like to express their special thanks to Prof. Mathias Czaika for his helpful suggestions and advice.

Funding Open access funding provided by Danube University Krems University for Continuing Education. This study was co-financed by the Asylum, Migration and Integration Fund and the Austrian Federal Ministry of the Interior, Grant no. BMI-IA123004/0046-III/5/a/2016 and GFF-NOE Dissertation Call, Project-ID: SC17-011.

\section{Declarations}

Conflict of interest The authors declare no competing interests.

Open Access This article is licensed under a Creative Commons Attribution 4.0 International License, which permits use, sharing, adaptation, distribution and reproduction in any medium or format, as long as you give appropriate credit to the original author(s) and the source, provide a link to the Creative Commons licence, and indicate if changes were made. The images or other third party material in this article are included in the article's Creative Commons licence, unless indicated otherwise in a credit line to the material. If material is not included in the article's Creative Commons licence and your intended use is not permitted by statutory regulation or exceeds the permitted use, you will need to obtain permission directly from the copyright holder. To view a copy of this licence, visit http://creativecommons.org/licen ses/by/4.0/.

\section{References}

Abadan-Unat, N. (Ed.). (1976). Turkish workers in Europe 1960-1975: A socio-economic reappraisal (Social, economic and political studies of the Middle East, Vol. 19). Leiden: Brill.

Abadan-Unat, N. (2011). Turks in Europe: From guest worker to transnational citizen. Berghahn Books. Akgündüz, A. (1993). Labour migration from Turkey to Western Europe (1960-1974). Capital \& Class, 17, 153-194. https://doi.org/10.1177/030981689305100107

Akgündüz, A. (1998). Migration to and from Turkey, 1783-1960: Types, numbers and ethno-religious dimensions. Journal of Ethnic and Migration Studies, 24, 97-120. https://doi.org/10.1080/13691 83X.1998.9976620

Akgündüz, A. (2008). Labour migration from Turkey to Western Europe, 1960-1974: A multidisciplinary analysis (Research in migration and ethnic relations series). Routledge Taylor \& Francis Group.

Akgündüz, A. (2013). Turkey: migration 18th-20th century. In I. Ness (Ed.), The encyclopedia of global human migration. Wiley-Blackwell.

Akgündüz, Y. E., van den Berg, M., \& Hassink, W. (2015). The impact of refugee crises on host labor markets: The Case of the Syrian refugee crisis in Turkey. IZA Discussion Paper No. 8841.

Aksel, D. B. (2014). Kins, Distant Workers, Diasporas: Constructing Turkey's transnational members abroad. Turkish Studies, 15, 195-219. https://doi.org/10.1080/14683849.2014.926233 
Aksel, D. B., \& Içduygu, A. (2018). National report on Turkey: Patterns of politicization on refugees and policy responses.. http://ceaseval.eu/publications.

Arslan, Ü., \& Ökten, Z. N. (2010). The relations between FDI and democracy: Evidence from Turkey. International Research Journal of Finance and Economics, (56), 111-123.

Arslan, I., \& van Wijnbergen, S. (1990). Turkey : Export miracle or accounting trick? Policy Research Working Paper Series(370).

Association Council. (1980). Decision No 1/80 of the Association Council of 19 September 1980 on the development of the Association.

Aydin, Y. (2013). Rückkehrer oder Transmigranten? Erste Ergebnisse einer empirischen Analyse zur Lebenswelt der Deutsch-Türken in Istanbul. ZÖSS Discussion Papers(36).

Aydin, Y. (2014). The new Turkish diaspora policy: Its aims, their limits and the challenges for associations of people of Turkish origin and decision-makers in Germany. SWP Research Paper, 10.

Bade, K. J. (2017). Migration, Flucht, Integration: Kritische Politikbegleitung von der "Gastarbeiterfrage" bis zur "Flüchtlingskrise" : Erinnerungen und Beiträge. Universitätsbibliothek.

Basch, L. G., Schiller, N. G., \& Szanton Blanc, C. (1994/2015). Nations unbound: Transnational projects, postcolonial predicaments, and deterritorialized nation-states. Routledge.

Baumeister, R. F., \& Leary, M. R. (1997). Writing narrative literature reviews. Review of General Psychology, 1, 311-320. https://doi.org/10.1037/1089-2680.1.3.311

Betcherman, G., Fares, J., McLaughlin, M., \& Puerto, S. (2008). Investing in Turkey's next generation: The school-to-work transition and Turkey's development (The World Bank 8084). https://econp apers.repec.org/paper/wbkwboper/8084.htm.

Biffl, G. (2012). Turkey and Europe: The role of migration and trade in economic development. Migration Letters, 9(1), 47-64.

Biffl, G. (2013). The role of migration in economic relations between Europe and Turkey. European Review, 21, 372-381. https://doi.org/10.1017/S1062798713000331

Bilgili, Ö., \& Siegel, M. (2014). Policy perspectives of Turkey towards return migration: From permissive indifference to selective difference. Migration Letters, 11, 218-228. https://doi.org/10.33182/ ml.v11i2.240

Bjerre, L., Helbing, M., Römer, F., \& Zobel, M. (2015). Conceptualizing and measuring immigration policies: A comparative perspective. International Migration Review, 49, 555-600. https://doi.org/ 10.1111/imre. 12100

Boeri, T. (2012). Introduction. In T. Boeri (Ed.), Brain drain and brain gain: The global competition to attract high-skilled migrants ; [prepared for the 11. European Conference of the Fondazione Rodolfo Debenedetti, held in Pisa in May 2009 (1st ed., pp. 1-14, Reports for the Fondazione Rodolfo DeBenedetti). Oxford: Oxford Univ. Press.

Bundesanstalt für Arbeit (1970). Ausländische Arbeitnehmer 1969: Beschäftigung, Anwerbung, Vermittlung - Erfahrungsbericht 1969 -. Ergebnis der Pepräsentativ-Untersuchung vom Herbst 1968. Nürnberg.

Caro, L. P. (2020). Syrian Refugees in the Turkish Labour Market. ILO Office Turkey.

Castles, S. (1986). The guest-worker in Western Europe - An obituary. International Migration Review, 20, 761. https://doi.org/10.2307/2545735

Castles, S. (2006). Guestworkers in Europe: A resurrection? International Migration Review, 40, 741766. https://doi.org/10.1111/j.1747-7379.2006.00042.x

Centel, T. (2017). Introduction to Turkish labour law. Springer International Publishing.

Cerna, L. (2016). ImmigrationpPolicies and the global competition for talent (International Series on Public Policy). Palgrave Macmillan UK.

Cerna, L., \& Czaika, M. (2020). Rising stars in the global race for skill? A comparative analysis of Brazil, India, and Malaysia. Migration Studies. https://doi.org/10.1093/migration/mnaa009

Chimhowu, A. O., Hulme, D., \& Munro, L. T. (2019). The 'New' national development planning and global development goals: Processes and partnerships. World Development, 120, 76-89. https:// doi.org/10.1016/j.worlddev.2019.03.013

Communications Center of TÜBITAK (TÜBIMER). (2020). TÜBIMER 2020. E-mail. Personal Communication .

Cooke, T. J., Wright, R., \& Ellis, M. (2018). A prospective onZelinsky's hypothesis of the mobility transition. Geographical Review, 108, 503-522. https://doi.org/10.1111/gere.12310

Czaika, M. (2018). High-skilled migration. Introduction and synopsis. In M. Czaika (Ed.), High-skilled migration: Drivers and polititcs (Vol. 1, pp. 1-19). Oxford University Press. 
de Haas, H. (2007). Migration and development. A theoretical perspective. Bielefeld: COMCAD - Center on Migration, Citizenship and Development. COMCAD Arbeitspapiere - working papers, 29.

Demet Güngör, N., \& Tansel, A. (2008). Brain drain from Turkey: The case of professionals abroad. International Journal of Manpower, 29, 323-347. https://doi.org/10.1108/01437720810884746

Demir, Ö., Acar, M., \& Toprak, M. (2004). Anatolian tigers or Islamic Capital: Prospects and challenges. Middle Eastern Studies, 40, 166-188. https://doi.org/10.1080/0026320042000282937

Demircan, F. (2020, February 17). Turkey's officials hold meeting to reverse brain drain: Steps to encourage reverse brain drain to Turkey from world discussed in meeting chaired by Turkish president. Anadolu Agency. https://www.aa.com.tr/en/turkey/turkeys-officials-hold-meeting-to-reverse-braindrain/1736840. .

Dişbudak, C., \& Purkis, S. (2016). Forced migrants or voluntary exiles: Ethnic Turks of Bulgaria in Turkey. Journal of International Migration and Integration, 17, 371-388. https://doi.org/10.1007/ s12134-014-0411-z

Dösemeci, M. (2013). The Turkish drawbridge: European Integration and the Cultural Economics of National Planning. Contemporary European History, 22, 627-647. https://doi.org/10.1017/S0960 777313000398

Dulger, I. (2004). Turkey: Rapid coverage for compulsory education- The 1997 Basic Education Program: Reducing poverty, sustaining growth-what works, what doesn't, and why a global exchange for scaling up success.

Düvell, F. (2014). International relations and migration management: The case of Turkey. Insight Turkey, $16(1), 35-44$.

Düvell, F. (2020). Shifts in the global migration order and migration transitions in Europe: The cases of Turkey and Russia. Comparative Migration Studies, 8, 45. https://doi.org/10.1186/ s40878-020-00204-2

Erat, V., \& Arap, İ. (2017). Kalkinmadan Rekabete Türkiye'de Planlamanin Dönüsümü. Uluslararası İktisadi ve İdari Incelemeler Dergisi, (18), 137-156.

ESI. (2005). Islamic Calvinists: change and conservatism in Central Anatolia. European Stability Initiative.

Eurofund (2017). 6th European Working Conditions Survey: Overview report (2017th ed., EF, 16/34). Luxembourg: Publications Office of the European Union.

Euronews (2020, December 8). Turkey orders arrest of 304 military personel over suspected ties to aborted 2016 coup. Euronews. https://www.euronews.com/2020/12/08/turkey-orders-arrest-of-304military-personel-over-suspected-ties-to-aborted-2016-coup.

European Commission. (2018). Mutual learning exercise (MLE) on national practices in widening participation and strengthening synergies: Topic report: Attracting qualified R\&D staff in the public and private sectors (Topic 1 Widening). https://rio.jrc.ec.europa.eu/sites/default/files/report/MLE\% 20Widening_Topic\%201\%20report.pdf.

Franck, P. G. (1970). Brain Drain from Turkey. In W. W. Marwel \& C. V. Kidd (Eds.), The international migration of high-level manpower: Its impact on the development process (pp. 299-373, Praeger special studies in international economics and development). New York, NY: Praeger.

Gökbayrak, Ş. (2012). Skilled labour migration and positive externality: The case of Turkish engineers working abroad. International Migration, 50, e132-e150. https://doi.org/10.1111/j.1468-2435. 2009.00520.x

Guresci, E. (2013). Rural immigration in turkey and agricultural problems. IOSR Journal Of Humanities And Social Science, 16, 63-70. https://doi.org/10.9790/0837-1646370

Hazen, H. D., \& Alberts, H. C. (2006). Visitors or immigrants? International students in the United States. Population, Space and Place, 12, 201-216. https://doi.org/10.1002/psp.409

Hönekopp, E. (1987). Rückkehrförderung und die Rückkehr ausländischer Arbeitnehmer und ihrer Familien. In E. Hönekopp (Ed.), Aspekte der Ausländerbeschäftigung in der Bundesrepublik Deutschland (pp. 287-342, Beiträge zur Arbeitsmarkt- und Berufsforschung, 114).

Içduygu, A. (2006). International migrants remittances in Turkey. Florence: European University Institute (CARIM Research Reports, no. 07). https://cadmus.eui.eu/bitstream/handle/1814/11687/CARIM_ ASN_2006_07.pdf; sequence=1.

Içduygu, A. (2009). International migration and human development in Turkey. UNDP, Human Development Research paper 52.

İçduygu, A. (2009). International migration system between Turkey and Russia: The case of project-tied migrant workers in Moscow (CARIM Research Reports 2019/8). 
İçduygu, A., \& Karaçay, A. B. (2012). The international migration system between Turkey and Russia: Project-tied migrant workers in Moscow. International Migration, 50, 55-74. https://doi.org/10. 1111/j.1468-2435.2011.00735.x

İçduygu, A., \& Kirişci, K. (Eds.). (2009). Land of diverse migrations: Challenges of emigration and immigration in Turkey (1st ed., İstanbul Bilgi University Press Migration research, Vol. 10). İstanbul: İstanbul Bilgi Univ. Press.

İçduygu, A., \& Sert, D. (2011). Project-tied labor migration from Turkey to the MENA region: Past, present, and future. International Labor and Working-Class History, 79, 62-80. https://doi.org/10. $1017 / \mathrm{S} 0147547910000311$

Insel, A., \& Sungur Cakmak, N. (2010). The impacts of the Turkish emigrants on Turkish exports and imports in Europe. MPRA Paper, 22100.

International Labour Force Law 6735 (2016). In Official Gazette No.29800 .

Jankowitsch, B., Klein, T., \& Weick, S. (2000). Die Rückkehr ausländischer Arbeitsmigranten seit Mitte der achtziger Jahre. In R. Alba, P. Schmidt, \& M. Wasmer (Eds.), Deutsche und Ausländer: Freunde, Fremde oder Feinde? ; empirische Befunde und theoretische Erklärungen : (Nebst) CD-ROM (pp. 93-109, Blickpunkt Gesellschaft, Vol. 5). Wiesbaden: VS Verlag für Sozialwissenschaften.

Karakoç, U., Pamuk, Ş., \& Panza, L. (2017). Industrialization in Egypt and Turkey, 1870-2010. In K. H. O'Rourke \& J. G. Williamson (Eds.), The spread of modern industry to the periphery since 1871 (pp. 142-166). Oxford University Press.

Kirilova, S., \& Kilic, H. (2012). „Roots-Migration“ türkeistämmiger Akademiker/innen und Student/ innen in Wien: Eine empirische Erhebung aus dem Jahr 2011(Dossier No. 30).

Kirişci, K. (2000). Disaggregating Turkish citizenship and immigration practices. Middle Eastern Studies, 36(3), 1-22.

Kirişci, K. (2007). Turkey: A country of transition from emigration to immigration. Mediterranean Politics, 12, 91-97. https://doi.org/10.1080/13629390601136871

Kuckartz, U. (2014). Qualitative text analysis: A guide to methods, practice \& using software. 1 Oliver's Yard, 55 City Road, London EC1Y 1SP United Kingdom: SAGE Publications Ltd.

Kuckartz, U., \& Rädiker, S. (2019). Analyzing qualitative data with MAXQDA: Text, audio, and video. Springer.

Kutlay, M. (2017). The Turks of Bulgaria: An outlier case of forced migration and voluntary return. International Migration, 55, 162-179. https://doi.org/10.1111/imig.12381

Lewis, W. A. (1979). Development planning: The essentials of economic policy. Allen and Unwin.

Lindquist, C. (2017). Educational reform in Turkey. International Journal of Progressive Education, 13(2), 133-143.

Lodewyckx, I., Timmerman, C., \& Johan, W. (2010). From nation state to migration state. Economics \& Sociology, (2), 9-22.

Lubambu, K. M. K. (2014). The impacts of remittances on developing countries. European Parliament. Directorate General for External Policies of the Union.

Martin, P. L. (1981). Germany's Guestworkers. Challenge, 24(3), 34-42.

Martin, P. L. (1991). The unfinished story: Turkish labour migration to Western Europe: With special reference to the Federal Republic of Germany. Internat. Labour Office World Employment Programme.

Martin, P. L., \& Miller, M. J. (1980). Guestworkers: Lessons from Western Europe. Industrial and Labor Relations Review, 33, 315. https://doi.org/10.2307/2522569

Massey, D. S. (1999). International migration at the dawn of the twenty-first century: The role of the state. Population and Development Review, 25(2), 303-322.

Mayring, P. (2014). Qualitative content analysis: theoretical foundation, basic procedures and software solution. Klagenfurt.

Mencutek, Z. S., \& Baser, B. (2018). Mobilizing diasporas: Insights from Turkey's attempts to reach Turkish citizens abroad. Journal of Balkan and Near Eastern Studies, 20, 86-105. https://doi.org/ 10.1080/19448953.2017.1375269

Meyers, E. (2000). Theories of international immigration policy-A comparative analysis. International Migration Review, 34, 1245. https://doi.org/10.2307/2675981

Milor, V. (1990). The genesis of planning in Turkey. New Perspectives on Turkey, 4, 1-30. https://doi.org/ $10.15184 /$ S0896634600000194

Müller, H. (2014). The dire state of labor rights in Turkey. The Turkey Analyst, 7(17).

OECD. (2012). Transferable skills training for researchers: Supporting career development and research. OECD Publishing. 
OECD. (2017). International migration outlook 2017 (41st ed.). OECD Publishing.

Oguzkan, T. (1976). The scope and nature of the Turkish brain drain. In N. Abadan-Unat (Ed.), Turkish workers in Europe 1960-1975: A socio-economic reappraisal (pp. 74-103, Social, economic and political studies of the Middle East, Vol. 19). Leiden: Brill.

Öndes, Ö. (2019, July 28). Bilim için Türkiye'ye döndüler (Returned back to Turkey for Science). Hürriyet. https://www.hurriyet.com.tr/gundem/bilim-icin-turkiyeye-donduler-41286384.

Öniş, Z. (2019). Turkey under the challenge of state capitalism: the political economy of the late AKP era. Southeast European and Black Sea Studies, 19, 201-225. https://doi.org/10.1080/14683857. 2019.1594856

Østergaard-Nielsen, E. (2016). Transnational politics: The case of Turks and Kurds in Germany. Routledge.

Paine, S. (1974). Exporting workers: The Turkish case (Occasional paper / Department of Applied Economics, University of Cambridge, Vol. 41). London: Cambridge Univ. Pr.

Parla, A. (2003). Marking time along the Bulgarian-Turkish Border. Ethnography, 4, 561-575. https://doi. org/10.1177/146613810344004

Penninx, R. (1982). A Critical review of theory and practice: The case of Turkey. International Migration Review, 16, 781. https://doi.org/10.2307/2546160

Peppler, L. (2018). Changes in highly skilled migration policies: Turkish-German medical migration since the 1960s. Migration Letters, 15, 491-502. https://doi.org/10.33182/ml.v15i4.1

Poot, J., Alimi, O., Cameron, M. P., \& Maré, D. C. (2016). The gravity model of migration: the successful comeback of an ageing superstar in regional science. Investigaciones Regionales - Journal of Regional Research, (36), 63-86.

Presidency of the Republic Turkey. Presidency of Strategy and Budget. (2019). Eleventh Development Plan (2019-2023).

Pusch, B., \& Splitt, J. (2013). Binding the Almanc1 to the 'Homeland': Notes from Turkey. Perceptions, $X \operatorname{VIII}(3), 129-166$.

Republic of Turkey. (1995). Law No. 4112 of 7 June 1995, Amendments to the Turkish Citizenship Act. Official Gazette No. 22311.

Republic of Turkey. (2009). Act No. 5901, Turkish Citizenship Law. Official Gazette No. 27256.

Republic of Turkey. (2012). Law No. 6304, Law on basic provisions of elections and voter registers Repealed provisions corpus for some applicable laws. Official Gazette No. 28296.

Republic of Turkey. Ministery of Development. (2013). The Tenth Development Plan (2014-2018).

Republic of Turkey. Ministry of Development. (2014). The Tenth Development Plan 2014-2018.

Ritter, G. (1972). Landflucht und Städtewachstum in der Türkei. Erdkunde, 26, 177-196. https://doi.org/ 10.3112/erdkunde.1972.03.02

Ronen, Y., \& Yanarocak, H. E. C. (2013). Casting off the shackles of Libya's Arab-Middle Eastern foreign policy: A unique case of rapprochement with non-Arab Turkey (1970s-2011). The Journal of North African Studies, 18, 494-508. https://doi.org/10.1080/13629387.2012.732279

Ryazantsev, S. V. (2009). Turkish communities in the Russian Federation. IJMS: International Journal on Multicultural Societies, 11(2), 155-173.

Sanchez-Montijano, Kaya A., \& Sökmen, M. J. (2018). Highly skilled migration between the EU and Turkey: Drivers and scenarios (FEUTURE Online Paper No. 21).

Schührer, S. (2018). Türkeistämmige Personen in Deutschland: Erkenntnisse aus der Repräsentativuntersuchung "Ausgewählte Migrantengruppen in Deutschland 2015" (RAM), 81, 80.

Senior Academic. (2019). Skilled migration towards Turkey. Istanbul.

Sirkeci, I. (2005). War in Iraq: Environment of insecurity and international migration. International Migration, 43, 197-214. https://doi.org/10.1111/j.1468-2435.2005.00338.x

Sirkeci, I., \& Pusch, B. (Eds.). (2016). Turkish migration policy (Migration series). Transnational Press.

Sirkeci, I., \& Zeyneloğlu, S. (2014). Abwanderung aus Deutschland in die Türkei: Eine Trendwende im Migrationsgeschehen? In S. Alscher \& A. Kreienbrink (Eds.), Abwanderung von Türkeistämmigen: Wer verlässt Deutschland und warum? (2014th ed., pp. 30-85, Beiträge zu Migration und Integration, Vol. 6). Nürnberg: Bundesamt für Migration und Flüchtlinge.

Sirkeci, I., Cohen, J. H., \& Yazgan, P. (2012). Turkish culture of migration: Flows between Turkey and Germany, socio-economic development and conflict. Migration Letters, 9, 33-46. https://doi.org/ 10.33182/ml.v9i1.201

Sirkeci, I., Cohen, J. H., \& Can, N. (2016). Internal mobility of the foreign-born in Turkey. In G. Catney \& N. Finney (Eds.), Minority internal migration in Europe (pp. 175-193, International population studies). London: Routledge. 
Sönmez Efe, S. (2020). Rights of migrant workers: An analysis of migration policies in contemporary Turkey. Transnational Press London.

State Planning Organization. (1963). Development plan. First Five Years (1963-1967).

State Planning Organization. (1967). Second five years development plan (1968-1972).

State Planning Organization. (1973). Third five years development plan (1973-1977).

State Planning Organization. (1979). Fourth five years development plan (1979-1983).

State Planning Organization. (1995). Seventh five years development plan (1996-2000).

Straubhaar, T. (1986). The determinants of workers' remittances: The case of Turkey. Weltwirtschaftliches Archiv, 122, 728-740. https://doi.org/10.1007/BF02707858

Tansel, A., \& Gungor, N. D. (2003). 'Brain Drain' from Turkey: Survey Evidence of Student Non-Return. SSRN Electronic Journal. https://doi.org/10.2139/ssrn.441160

Tas, H. I., \& Lightfoot, D. R. (2005). Gecekondu settlements in Turkey: Rural—urban migration in the developing European periphery. Journal of Geography, 104, 263-271. https://doi.org/10.1080/ 00221340508978648

Thränhardt, D. (2003). Der Nationalstaat als migrationspolitischer Akteur. In D. Thränhardt \& U. Hunger (Eds.), Migration im Spannungsfeld von Globalisierung und Nationalstaat (1st ed., pp. 8-31, Leviathan Sonderheft, Vol. 22). Wiesbaden: Westdeutscher Verlag.

Todaro, M. P. (1980). Economics for a developing world: An introduction to principles, problems and policies for development. Longman.

Tören, T. (2018). Documentation report: Syrian refugees in the Turkish labour market (ICDD working papers, no. 22 (July 2018)). Kassel: kassel university press GmbH.

TÜBITAK. (2010). 2011-2016 Bilim ve Teknoloji Insan Kaynagi Stratejisi ve Eylem Planı: (Science and Technology Human Resources Action Plan 2011-2016).

TÜBITAK Expert. (2019). Skilled migration towards Turkey. Istanbul.

Tuncer, B. (1971). Development of the Turkish economy: An experience in planning. Discussion Papers.

Turkish Republic Prime Ministry. State Planning Organization. (2006). Ninth development plan 2007-2013.

Ünver, C. (2013). Changing diaspora politics of Turkey and public diplomacy. Turkish. Policy Quarterly, 12(1), 181-189.

Üstübici, A. (2019). The impact of externalized migration governance on Turkey: Technocratic migration governance and the production of differentiated legal status. Comparative Migration Studies, 7 , 1-18. https://doi.org/10.1186/s40878-019-0159-x

Yavuz, M. H., \& Balci, B. (Eds.). (2018). Turkey's July 15th coup: What happened and why. University of Utah Press.

Yaycı, C. (2019). Irak’ta Yaşanan Savaşlar ve Türkiye’ye Etkileri. Güvenlik Stratejileri Dergisi, 15, 331352. https://doi.org/10.17752/guvenlikstrtj.620961

Yildiz, N., \& Köktürk, E. (1983). Ländliche Neuordnung in der Türkei. Annales de la Faculté de Droit d'Istanbul, 29(45), 247-261.

Yilmaz, A., \& Güler, T. (2016). AK Parti Hükümetleri Döneminde Siyaset ve Bürokrasi Arasindaki Güc Mücedelesinin Devlet Planlama Teskilati Üzerinden Okunmasi. Yönetim ve Ekonomi Araştırmaları Dergisi, 14(2), 294.

Zelinsky, W. (1971). The hypothesis of the mobility transition. Geographical Review, 61, 219. https://doi. org/10.2307/213996

Publisher's Note Springer Nature remains neutral with regard to jurisdictional claims in published maps and institutional affiliations. 